\title{
Communication technologies and legitimate consumption: making sense of healthcare remittances in Cameroonian transnational relationships
}

\author{
Primus M. Tazanu
}

\begin{abstract}
Introduction
This article addresses what is evaluated as legitimate consumption within the Cameroonian transnational social sphere. My specific focus is on the role played by information and communication technologies (ICT) in Cameroonian transnational resource redistribution spurred by expectations of reciprocity but underpinned by mistrust. The mistrust centres on non-migrants using ICT to request money for what the remitters (migrants) see as unnecessary expenditures. Legitimate consumption is a negotiated outcome of complex reciprocity expectations, obligations and evaluations. Such evaluations delineate what does not and should not count as deserving financial support from abroad. What actors do with the media, and what they believe the media can do for them within the framework of acceptable remittances, is partly informed by the history of gifts and reciprocity in Cameroon. This became more visible with the introduction of a common currency and the monetization of socio-economic transactions in the late nineteenth century.

Much has been written about ICT and remittances, and especially about how using mobile phones has transformed the act of sending money home. It is now hard to imagine transnational remittances without reference to the mobile phone or the internet. These ICT provide a shared 'communication infrastructure' (Couldry 2004: 357) for remitters and recipients of funds to interact across borders. ${ }^{1}$ There has also been attention paid to the ways in which instant financial requests have altered the relationships between remitters and recipients (Nyamnjoh 2005; 2011; Tazanu 2012b; 2015a; 2015b; Horst 2006; Madianou and Miller 2011; Horst and Miller 2006; Hunter 2015; Hernández-Carretero 2015). Studies show that the theme of remittances features prominently in phone conversations between migrants and non-migrants (see also Drotbohm 2010: 62; Horst 2006: 155; Vertovec 2009: 58; Tazanu 2012b: 199; Mahler 2001). Key points of discussion include who receives monetary support, when they do so and, more importantly, for what purposes the money is remitted.
\end{abstract}

Primus M. Tazanu is a social anthropologist and postdoctoral fellow based at the Wits Centre for Diversity Studies, University of the Witwatersrand in Johannesburg. He is the author of Being Available and Reachable: new media and Cameroonian transnational sociality (Langaa, 2012). Email: tazanu@gmail.com

${ }^{1}$ The Cameroon government is disrupting the internet as a shared communication infrastructure. From mid-January to mid-April 2017, it disconnected internet services in the Anglophone part of the country where citizens are protesting about marginalization. People living in the Anglophone zone resorted to travelling to the Francophone side of the country to collect remittances after the disconnection.

(C) International African Institute 2018 
Transnational remittance practices reveal the connection between physical and socio-economic mobility and financial insurance for transnational families.

ICT are often seen primarily as tools that facilitate long-distance communication between transnational families. However, the meaning attached to these media and the ways in which they are used can engender unease in transnational family ties. The Cameroonian example presented here reveals that expectations of gifts and reciprocity between those connected across borders take unanticipated directions. This is seen when migrants either fail to reciprocate or are instantly reminded, through the mobile phone, to honour financial obligations to their families. What is described in this article, then, is interpreted within the anthropology of exchange as expectations of reciprocity gone wrong. This approach is informed by classical works in anthropology that have found that gifting is often unbalanced. Anthropology of exchange tells us that giving gifts and practising reciprocity supposedly cement social bonds (Mauss 1954; Carrier 1991; Sherry 1983), but gift-giving is a form of social obligation that may reflect either social closeness or distance (Carrier 1991: 120). Carrier states that we cannot separate objects from the relationship and the people involved in the transaction (ibid.:133), meaning that the transactions are part and parcel of social bonds, and that actors give or receive gifts based on their positions within a socio-cultural context that tells them what is an appropriate gift (ibid.). A subordinate is generally not expected to return gifts with an equivalent value, and some people are absolved from giving (Sherry 1983: 160). As will be seen in what follows, the socio-economic positions of actors in transnational relationships typically determine who is expected to give more.

Emphasizing the centrality of direct communication, and the possibilities and frictions surrounding remittances, I will show how healthcare specifically has come to be considered a legitimate and 'moral' form of consumption for which money should be sent. In a context of suspicion that money from abroad might sponsor 'unnecessary' lifestyles in Cameroon, remittances destined for healthcare are considered the exception. The negotiation of remittances has been streamlined to specify that medical treatment is something actors evaluate as falling within the realm of important expenditure.

The centrality of ICT to the process of direct requests and negotiation of remittances is located within a context where these media have eased connectivity between Cameroonians across borders to an extent not possible in the past. By the time of the fieldwork, it had become so normal for Cameroonians to use new media - especially mobile phones - to maintain transnational social ties that participants claimed not to be able to imagine life without these communication devices. The mobile phone has become entwined in the lives of Cameroonians, penetrating both urban settings and far-flung rural areas (Nyamnjoh 2004; Nkwi 2009). Actors do not, however, get in touch with each other on an equal basis: it is primarily migrants who maintain the relationship - due to their relatively higher socio-economic position.

\section{Methodology}

Remitting money for family healthcare - alongside education and emergency funeral expenses - emerged as a key motive for sending financial support to 
Cameroon. This became evident from my fieldwork among Cameroonians in Freiburg in Germany, and in Buea in Cameroon, in 2009 and 2010, and it continues to surface in my conversations and email exchanges with them. The research formed part of multi-sited fieldwork on the significance of ICT in Cameroonian transnational relationships (Tazanu 2012b). Most migrant participants for the research were drawn from Scratch My Back, an organized group of Anglophone Cameroonians in Freiburg, which functions as a social support system and whose members, in addition to attending monthly gatherings and communal meals, come together to assist one another in times of joy or sorrow. Financial contributions are made, for example, to support members who give birth or those who lose their parents. I was a registered member of the group, hosted some of their meetings, and was obliged to attend the group's events and to contribute financially and in kind. When I left Freiburg in early 2013, the group was planning to register itself at the local municipality. It was also planning to raise funds to support schools back in Cameroon. Unlike in Freiburg, where I had been hesitant to ask whether the Africans I met in the city were Cameroonians, the process of recruiting research participants in Buea was relatively smooth. I tried to fit into the flow of urban life there, and was able to start conversations in spaces such as internet cafés, public phone facilities, restaurants, car wash points, and so on. In internet cafés, where I encountered most of my research participants, I started conversations when the internet disconnected or was slow, or when the electricity went off. The friends I made at this site of sociality expanded my network, from which I drew more participants. Participants were also drawn from my network of family and friends in Buea and beyond. In order not to alienate those who could not communicate in English, a language of the elite, I started conversations in Pidgin, the lingua franca of urban areas in Anglophone Cameroon.

The research was conducted through in-depth individual face-to-face narrative interviews, as well as participation, observation and group interviews. Interviews were recorded and later transcribed. Fifty-five of the seventy-four participants were between the ages of twenty and thirty, and twenty-six resided in Freiburg and forty-eight in Buea. They were assured of their anonymity (all names used in the article are pseudonyms). When doing research among Cameroonians in Freiburg, our similar backgrounds and experiences provided a point of commonality, and my status as a Cameroonian migrant influenced my understanding of their narratives. This in turn - despite much reflexivity and self-questioning impacted on the production of knowledge in this article (see also Wiles 2008: 121-2; Salzman 2002: 807; Sultana 2007: 376-8; Mullings 1999: 337; Tsuda 1998: 107).

\section{Contextualizing gifting and reciprocity in Cameroon}

Cameroonians associate migration with upward socio-economic mobility (MataCodesal 2015: 2277; Hernández-Carretero 2015: 2030). Young people believe that migrating out of the country is a promising avenue for accessing and accumulating resources through work abroad. Migrants are expected to succeed in their new contexts and, in turn, share their successes by supporting the family that stays 
behind (Alpes 2012; Nyamnjoh 2005; 2011; Frei 2012; Tazanu 2012b). Those who migrate mainly to the West to 'accumulate money or refine their skills' (Jua 2003: 22-3) are known as bushfallers in the Anglophone part of the country. 'Bush' metaphorically denotes an uncultivated piece of land, offering great potential rewards to those who venture into it. 'Faller' in this context means someone who ventures to exploit these opportunities (see also Alpes 2017: 306-7). Bushfallers often demonstrate their successes through extravagant consumption, often focused in urban areas, when they visit home. They invest in family housing and bear greater responsibility in maintaining transnational relationships through phone calls and material support to people back in Cameroon.

Most research participants in Freiburg were students who worked part time and remitted money to their families. In Cameroonian transnational family relationships, adult migrants, irrespective of their migration status, gender or socio-economic condition abroad, are expected to support those who stay at home (Jackson 2014; Tazanu 2010; Rowlands 1996; Nyamnjoh 2002; Geschiere and Gugler 1998).

Scondary literature about socio-economic and political transformations in the country after German colonization in the late nineteenth century reveals the background of reciprocity, exchange, migration and remittances in Cameroon.

The plantations established by the Germans in the coastal areas became a major source of attraction for migrant labour from the hinterlands of the southwestern part of the country in the early twentieth century. All members of Scratch My Back came from these hinterlands and coastal areas, where Buea is also situated. Labour migration to the coastal areas and the attendant social transformations, including those affecting reciprocity and exchange, were primarily induced by the monetization of the economy, which contributed to socio-economic inequality. With the introduction of a common currency, people migrated to areas where they could earn 'cash income which could not be securely and regularly obtained' in the villages where trade and agriculture were still underdeveloped (Ardener et al. 1960: 221; see also Ouden 1987: 19). Ardener et al. (1960) conducted a survey in the late 1950s among coastal plantation workers. One of their interests was what motivated the young migrants to seek employment at the Cameroon Development Corporation (CDC), a large-scale agro-industrial company set up in 1947 by amalgamating the German plantations. Their reasons for migrating centred mainly on expectations of upward socio-economic mobility: they migrated to work for money to buy clothes, to acquire business capital, and to pay bridewealth and meet other marital obligations. They also wanted to support their (often poor) families back home. Some of them wanted to have earned the respect of their villages when they returned.

The obligation placed on young people who migrated to the coast to work in these plantations to support their kith and kin back in the villages arose from the dearth of paid work in these areas, and the small amount of currency in circulation. Those who stayed behind in the villages felt entitled to share in the achievements of the migrants. They requested money from migrants to pay taxes and cover necessities such as children's education, labour, or hospital bills. These remittance practices became some of the most contentious issues in the relationship between migrants and their friends and family who stayed behind. The migrants' frequent complaint that they had no money to send back home disappointed the villagers. Some of those who stayed behind then embarked on journeys 
to the coast 'perhaps with the particular object of collecting some gift', such as money (Ardener et al. 1960: 184). These villagers' imagination of the good life on the coast was partly informed by the money and material successes that migrants displayed when returning home; these included the consumption of scarce European goods. Migrants were seen to easily honour expensive bridewealth obligations, a practice that left their non-migrant peers envious (Brain 1972: 122).

This does not mean, however, that benefits and gifts flowed in only one direction, from migrants to their relatives back home. Ardener et al. (1960) report that these workers stayed strongly connected to their villages in many ways. Most of them still retained land, which had to be taken care of by their families. Although physically absent, they were represented in family and village meetings, and contributed money to village development. In the early days of migration, it was mainly young men who moved to the coast. Those who were married relied on their parents to take care of their children and wives (who in turn took care of their husband's parents and contributed labour to their husband's family). Moreover, the village provided other forms of security for migrants who returned in times of illness in order 'to be cured by their own medicine men and to seek the protection of their own family gods and ancestors' (Ouden 1987: 17). They also received medication, special food, charms and amulets from the villagers. These intimate and intricate connections to the village often culminated with the burial of migrants in their villages or in their parents' villages of origin (Geschiere and Gugler 1998: 311; Jua 2005).

Relationships of exchange and reciprocity between migrants and those who stayed behind therefore persisted, even if they were on an unequal basis. Still, issues arising from the physical distance between migrants and their kin, and the resultant mismatch between expectations and actual responses to appeals for support, affected the quality of these relationships in ways that neither the migrants nor those who stayed behind had anticipated. Serious tensions arose over the redistribution of migrants' income. Parents in the villages demanded that their children not waste money at the coast; that they live frugally and not squander their perceived wealth on what was deemed unnecessary consumption. Attempted control by elders in the villages also involved parents telling their children to send money back home if they had no immediate need for the money they earned at the coast (Argenti 2007: 184). The elders back in the villages saw the young migrants as being less responsible with money. In the next section I discuss how this situation was affected by new communication media, especially mobile phones, which mediated these expectations of remittances and resource allocation in Cameroonian transnational families.

\section{Mobile phones, remittances and reciprocity}

While some Cameroonians who migrated to Europe at the turn of the century kept in contact with their families through letters and arranged landline telephone calls, the young participants in my research found it difficult to imagine how these ties had been maintained without ICT. What they had in common with these earlier waves of travellers, however, was the pressure of the obligation to stay in touch. 
The research participants believed that family ties were best sustained through phone calls and material exchanges. In this section, I focus on material exchanges by describing the role of ICT in raising non-migrants' expectations of support from migrants, and why these expectations often remained unmet. Bushfallers told me that they were worried that the mobile phone offered a too direct medium for non-migrants to request remittances. Non-migrants, however, expected migrants to take advantage of instant communication to reciprocate the support they received from their families, on whom they had relied when they were still living in their home communities in Cameroon. Within this framework, it was rational for them to expect support from bushfallers who are perceived as having attained upward socio-economic mobility.

\section{'They just amass the wealth for themselves': tensions of dependency and interdependency}

Studies on transnationalism most often focus on migrants' activities and experiences, downplaying the fact that non-migrants are active participants in crossborder interactions as well (Abranches 2014: 262). Attention has thus been paid to the fact that migrants send remittances, use new media to maintain ties with home, and visit their home countries. Research on the Cameroonian transnational family has exemplified this emphasis. Findings on the significance of mobile phones on remittance practices dominate these studies (Nyamnjoh 2005; 2011; Alpes 2012; Tazanu 2012b). In his article on the mobile phone and Cameroonian transnational family ties, Nyamnjoh (2005) concludes that migrants generally feel uncomfortable that this medium provides a direct avenue for nonmigrants to easily request remittances from abroad. Following up on this, in my own research I have looked at the implications of the possibilities of instant money transfer opened up by the mobile phone. Framing studies in this way reproduces the privileged position of migrants, who are understood to have more financial resources and more agency than their stay-at-home relatives. From this perspective, the mobile phone is seen as a tool that coordinates and channels remittances back to Cameroon (Tazanu 2012b; 2015a; 2015b). However, as I argue below, transnational relationships can also be studied by focusing on giving and reciprocity - or, more precisely, on expectations of reciprocity gone sour.

An optimistic assessment of the mobile phone as a technology that connects transnational families often conceals the uncomfortable nature of these interactions, often determined by the technology itself. When evaluated positively, for example, the conclusion is justified that non-migrants can immediately and directly access information about the migrants' needs for food, medicine or clothing from home. Instant connectivity can also easily be interpreted as facilitating the transmission of remittances from abroad. Gifts from home and from abroad ideally cement the social ties between migrants and non-migrants. However, my study reveals that such a positive picture is ultimately inaccurate. One of the main problems with instant communication - expressed by both sides - centred on reciprocity and remittances. From the perspective of non-migrants, many migrants failed to honour their pledges to send money back home. Concomitantly, migrants reported experiencing excessive pressure for money; each bushfaller was connected to many family members and friends, all with 
specific monetary demands (see also Hernández-Carretero 2015: 2027; Hunter 2015). The supposed pressure to remit led to the migrants limiting the number of people with whom they maintained ties. For example, Glory, a twenty-sevenyear-old student living in Germany, described her experience of the pressure to remit, and explained why she needed to 'filter' the number of people in Cameroon with whom she maintained ties:

I have filtered my relations. There are many that I do not contact because they are very reluctant to write. There are others who I do not feel at ease calling them because I know the first thing they would ask is money. They talk only about problems. So, I filter this type of relation and I am reluctant to call them. I may contact them only once in a while or not at all.

Glory had to work part time at an old people's home while completing her studies. She was unable to convince her family and friends in Cameroon of the difficulties she faced in her life abroad. In 2007, just a few months after arriving in Germany, her younger sister requested money to set up a tailoring workshop in Cameroon. Glory was able to provide only part of the money, much to the dissatisfaction of her sister. Glory was disappointed when she later learned that her sister had not set up the workshop at all. The relationship between the two sisters became so sour that they no longer talked to each other. In my fieldwork, stories such as Glory's were common. Migrants were suspected of withholding money, or 'refusing to share the benefits of living in Germany', according to another immigrant, Michael. He visited Cameroon in June 2009 and thought he had won the sympathies of his family after he explained to them the difficulties of living abroad as a foreign student. Michael was thus surprised when his brother demanded money, a laptop and a mobile phone a few days after he returned to Freiburg. In anger and disappointment, Michael blocked his brother's number.

Blocking a person's phone number was one of the many practices used by migrants to distance themselves from unwanted relationships. Other distancing strategies included ignoring calls from Cameroon, as well as not sharing phone contacts in the first place (see also Tazanu and Frei 2017). These practices were interpreted in Cameroon as a tactic by bushfallers to sever ties of interdependency within the family. The narrative has thus emerged that bushfallers are unwilling to share their achievements. This view was expressed by most participants in Buea, including twenty-four-year-old Adeline, a university graduate. She had no reliable source of income and believed that it was the duty of her aunt in Ireland and uncle in England to support her financially. But these family members were not willing to assist her. She said:

But we find in a nutshell that they do not really want to share. They do not share. They only make you to know they have. And you actually see that they have. They spend money and move around with women but they do not give things out. This means they just amass the wealth for themselves.

Despite directing her disappointment at both her uncle and aunt, in her descriptions of bushfallers Adeline constructed a gendered figure of migrants as men who squander money on women when they visit Cameroon. In her narrative, this is money that should be invested in sustaining family ties. By describing 
migrants' successes as 'the wealth', Adeline conveyed an idea of plenty, implying that part of this rightfully belonged to the family in Cameroon because of a reciprocal entitlement they had to bushfallers' resources. While stressing their right to migrants' resources, the research participants in Buea detailed interdependency within the family and the sacrifices they had made in order to send a bushfaller overseas. These sacrifices included the sale of land, houses, businesses, cars and farms, as well as incurring debt 'just to make sure they go abroad', according to Amos, a nineteen-year-old cybercafé attendant. ${ }^{2}$ He reasoned that, because of these sacrifices, it was rational for them to expect assistance from migrants (see also Alpes 2017: 306). While referring generally to migrants' obligations to their families, his statement was informed by his own experience of reciprocal ties with a cousin in the US. It was thanks to family support, including a contribution from Amos's late father, that this cousin had been able to migrate to the US. Amos, Adeline and many other participants in Buea believed that it was only fair that migrants who had relocated should pay back the favour to their relatives who had stayed (see also Åkesson 2011: 336). Whether migrants were unable or unwilling to send support home was not particularly a concern for participants in Buea; non-migrants believed that bushfallers wilfully wanted to destroy relationships by keeping vital resources to themselves (Tazanu and Frei 2017: 86-7). This explains why some of them used mobile phones to remind bushfallers of their obligations to their families in Cameroon.

Cole has observed that Malagasy women in France, like other African migrants, are generally considered 'important nodes in networks of material and affective exchanges' (2014: 277). These migrants are perceived as people who possess 'life-transforming powers' for those who stay behind (ibid.: 280). However, although they have achieved high status and are regarded as privileged, they soon realize that it is difficult to sustain the expectations of non-migrants from this position. Based on her study of Guinea-Bissau, Abranches observes that ' $[\mathrm{h}]$ ome-based kin also condemned selfish behaviours among their migrant relatives, for instance, when the remittances or other kinds of support received were considered insufficient' (2014: 269). Evidently, even as the gift of money demonstrates migrants' power and their commitment to the family, it also generates narratives of migrants' stinginess, and inevitably also of the ungratefulness of the recipients of the gifts. Interestingly, research participants in Cameroon were reluctant to acknowledge that they received money from family members living abroad. The young people who did acknowledge doing so undervalued the support and stated that the assistance was far below what they expected. They expected to receive large amounts of money, money that they hoped would transform their lives (Tazanu 2015a).

For non-migrants, bushfallers do not reciprocate enough. The anthropology of gifting and reciprocity holds that relationships risk breaking up if actors do not repay gifts (Weiner 1980: 72; Carrier 1991: 123). This would mean that the

\footnotetext{
${ }^{2}$ A cybercafé attendant helps customers to surf the internet. One of his or her main duties is to assist customers to check their emails. With increasing internet literacy, most of those accessing the internet from cybercafés no longer need the services of these attendants. The advent of smartphones has also meant that most Cameroonians no longer access the internet from cybercafés, which was the case a few years ago.
} 
migrants' perceived failure to nourish the relationship threatens family ties. And these transnational families are characterized by plenty of gifting. For example, I took gifts from migrants in Germany to their families in Cameroon and vice versa when I conducted fieldwork in the two countries. But I refrained from sharing information about the migrants or non-migrants with each other, for fear of becoming implicated in family gossip and quarrels. Some of the migrants who participated in my study received gifts of clothes, food, spices, medicine, amulets, photographs, letters and asylum support papers, among other things, from non-migrants back home (see also Abranches 2014). I also delivered money, clothes, mobile phones, shoes, books and perfumes to families and friends in Cameroon. Observing that such gifts flow from non-migrants to migrants helps explain non-migrants' expectations, which are underpinned by the logic of gift-giving. Their anticipation of support from bushfallers generally draws on one of two kinds of earlier action: either the giving of material gifts from home, or the original provision of assistance to migrants by family. In this sense, family expenditure on the bushfaller is an investment (Alpes 2017). The family can make a claim on this investment when the migrants achieve upward socio-economic success, as argued by Amos and Adeline.

The anthropology of gifting and reciprocity postulates that gifts foster social bonds; they bind the receiver and the giver, who feel obliged to reciprocate (Carrier 1991: 120; Sherry 1983: 157-8; Abranches 2014: 268). Actors understand that their gifts will be repaid in one way or another in the future. In theory, this means that the actors involved in gifting patiently wait for their gift to be reciprocated. But in the cases I studied, actors were not necessarily patient when waiting for their gifts to be repaid. Non-migrants used mobile phones to demand directly that bushfallers repay the support they had received from their families when they were still in Cameroon. The family back home took advantage of the immediacy and directness of mobile communication, which left little room for being unavailable, to demand repayment of their gifts. Put differently, the perceived higher socio-economic status of migrants and the reality that they can easily be reached to honour obligations to the family contribute to the breakdown of the 'rules' of reciprocity (Jackson 2014: 56). This is unlike many understandings of reciprocity, where the relationship between givers and recipients is understood as promoting harmony.

It should be emphasized that the expectation to support those who stay at home does not emanate only from non-migrants. Of course, migrants do feel obliged to reciprocate, especially when it comes to the generosity of the older generation. This means that they accept that at least some non-migrants are entitled to lay claim to their resources. In her study of family obligations and migration in Cameroon, Fleischer (2007) observes that most young Cameroonian migrants wish to remit to their families. In this way, they are reciprocating for the support provided to them in the past by their family (see also Jackson 2014: 53-4). For example, George in Freiburg felt obliged to send money to his sister and her husband, who had adopted him at the age of five when their father died. He believed it was 'a moral duty to pay back the money they spent on me'. George was doing for 'other family members what the older generation did for' him. All the migrants I spoke to expressed similar sentiments. They said that the family they presently supported or wished to support had helped them in the past. Elsewhere in Africa, Lindley reports that Somalian immigrants 
in London feel that they 'owe their parents, and often older brothers or uncles, for earlier material and non-material assistance: for bringing them up, helping with their education and sometimes paying for them to go overseas' (2009: 1324). Similarly, Dorine, a twenty-three-year-old medical student in my study, praised Cameroonian parents and guardians for helping them 'to get here [Germany]' and said 'it is time' for them to 'pay back'. After she migrated to Germany, her parents not only stopped supporting her, they also started asking her to support them financially. Dorine believed that this changed relationship between herself and her parents was as it should be.

This narrative that non-migrants should be supported, however, must be read in part as an ideal representation of what the actors thought the relationships should be. In reality, most participants contended that direct requests for remittances, if they were not accompanied by nobler sentiments of concern and care, contributed to the breaking of family ties. Migrants described their family members in Cameroon as insensitive and inconsiderate, for instance, when they asked only for remittances and did not seem interested in how the bushfallers were coping with their new lives abroad. In his study on Cuban intimacy and belonging, Simoni observes that those who remained on the island 'found it hard to empathise or to understand and relate' to the experiences of migrants. His conclusion is based on the observation that Cubans who stayed at home often treated migrants as a 'Euro with legs, as a dollar walking' (Simoni 2015: 35). Likewise, Lindley says that Somalian immigrants in London felt that family members back home 'measure affection in remittances' (2009: 1327). Similarly, the migrants in my study categorized inconsiderate requests for money as being more like commodity exchanges, where the value of the exchange is more important than the relationship, and where they do not necessarily need to have enduring ties (Carrier 1991: 121). Furthermore, when the migrants saw the relationship as resembling commodity exchange, it suggested that their families back in Cameroon separated the gift from the giver. Seeing it in this way would mean that the transaction were no longer part of the social bond, as is expected in gift exchange. Such an interpretation of these social interactions further exacerbates the unease in these relationships.

\section{Concealing the 'truth': remittances at all costs}

In his review of Mauss's work on the gift, Carrier emphasizes that: 'In societies dominated by gift exchange the structure of kinship typically provides the basis for people's identities, relations, and obligations' (1991: 129). Gift exchange is a prominent feature in Cameroonian transnational families. The giving of gifts is unbalanced, however: bushfallers are expected to give more than their nonmigrant relatives. Abranches has observed in Guinea-Bissau that gift 'returns and compensation are expected' between migrants and non-migrants in transnational families. However, this does not automatically translate to 'balanced reciprocity' in which non-migrants give gifts that are equal in value to the ones they receive from migrants (Abranches 2014: 272). My findings reveal that bushfallers see themselves as potential losers in the relationship because they are expected to give more. They worry that non-migrants could use the mobile phone to outwit them. In fact, most migrants interpreted 'call me back' requests and other 
media practices used by non-migrants as strategies to extract remittances at all costs.

Such suspicions are not unfounded. Many non-migrant youths in Buea told me that they use their mobile phones to communicate their economic vulnerability. In his work on different facets of remittances, Carling finds that non-migrants request money by positioning themselves as desperate people, in need of rescue by their migrant relatives abroad (2014: 240-1). Similarly, non-migrant family members in my study resorted to justifying demands for remittances by stating a morally meaningful purpose for which they would use the money (see also McKay 2007: 188-9). These family members were aware that their subordinate position in the relationship meant that they could not engage in meaningful negotiation with bushfallers without relying on the latter's goodwill. But this was no deterrent to their endeavouring to request money from relatives abroad. Some young people admitted that they tricked bushfallers into sending money to cover an emergency. They would exert pressure on bushfallers, expecting this to result in instant returns. A few of them boasted about their ability to outwit migrant brothers and sisters. Students detailed how they sent emails with inflated prices of books, fabricated stories about internships, and - at the beginning of the school year lists of fake new books that had to be bought.

Non-migrants' strategy for outwitting 'greedy' migrants by making morally meaningful demands (Carling 2014: 250) did not go unnoticed by migrants. Miranda, then twenty-nine years old, was studying to become a health assistant at an old people's home. Her two brothers in Cameroon frequently demanded money for educational and health-related matters. She was familiar with morally meaningful requests, which she had made herself a few years earlier when she was still in Cameroon. She said:

I believe my brothers are crooks. They never tell me that they need money to go out drinking with girls ... I cannot believe that they do not take women out for drinks or that they do not drink beer. They have never asked me money for a beer. They ask for money only for things that they believe I will feel pity for.

Miranda was convinced that her brothers spent money on beer, girlfriends and parties, even though they requested money only for school and health-related purposes. She categorized her brothers as 'liars who do all they can in order to get something from us'. Bushfallers believed that non-migrants feel empowered to use the mobile phone to make requests because of the absence of co-locality. These actors thus have a certain freedom to express their sense of having an entitlement to the migrants' earnings. In this sense, the phone virtually collapses the distance between the bushfallers and the non-migrants, making it difficult for migrants to conceal their real or imagined successes (Jackson 2014; Nyamnjoh 2005). Spurred by their imagination of life in the West, non-migrants interpreted bushfallers' reluctance to remit money as a form of greed. It was somehow 'right' if they used any means, including deceit, to get money from uncaring migrants.

These practices of using the phone to trick and pressure migrants into remitting money have created an atmosphere of mistrust in which bushfallers streamline what they are ready to remit money for. The young research participants in Buea admittedly made their demands as morally meaningful as possible in order to circumvent the stringent remittance standards set by the bushfallers. In other 
words, what they intended to use the money for had to fall within what was assessed as legitimate consumption.

\section{Legitimate consumption: making sense of Cameroonian transnational healthcare remittances}

The classification of a certain category of consumption as 'legitimate' - expenditures that the actors involved qualify as necessary and justifiable - points to the ways in which transnational families attempt to allocate financial resources amidst tensions and mistrust. These are expenditures that appeal to the sentiments of the actors and are considered non-wasteful by the remitters. The migrants in Freiburg positioned themselves as responsible individuals who were ready to assist non-migrant family members when necessary. At the same time, they described themselves as cautious actors who were not prepared to redistribute their money carelessly. It was for this reason that they stipulated that remittances for healthcare were morally justifiable and thus merited assistance from them. Healthcare support, as described in this context, highlights what bushfallers saw as a moral obligation to their non-migrant family members.

When William migrated to Germany in the late 1990s, he kept ties to his family through letters and the home landline. By 2002, he could communicate with them using a mobile phone. His reactions to requests for remittances from the family were immediate in the early days of the mobile phone. However, he soon realized that manipulation and deceit were on the increase when each of his siblings owned a personal phone and some of them made secret calls to him (Andersen 2013; Miller and Slater 2000: 16, 20) to request money to help solve non-existent problems. He contrasted this with the past, when family members all gathered and interacted with him on the home landline. In the context of his siblings attempting to pursue their narrower personal interests through direct calls, William concluded that the mobile phone was a technology of deceit. Through their mobile phones, William's siblings individually informed him about financial needs in the family in Cameroon. But other family members were not aware that money had been solicited on their behalf. After he had narrated these experiences of deceit, I asked William if his priorities when making remittances had changed over time:

Of course, they are different. I give priorities to illnesses, deaths, accidents, education, etc. ... Something serious that has to do with the life of someone. Health is important. It is the same for family members and close friends. Those are my priorities. The closer the person is to the family, the more important it is. In the beginning the people did not have many priorities when they kept in touch besides [unnecessary] demands, but since I told them that I do not welcome such calls, they have scaled down their preferences. They call me now for important things. From my point of view, some things are not important.

Before arriving at a stage when they deemed a demand to be 'serious', participants such as William had realized that most non-migrants made 'unnecessary demands'. Some of them requested money for weddings, transportation to the city or village, house rental payments and daily living expenses. After much contention over what should count as 'serious' expenditure, the actors came to a 
common understanding that education, health and death should top the list of priorities (Tazanu 2012b). In her research on Senegalese transnationalism, Hernández-Carretero found that the reason non-migrants requested money only for important things was because it was difficult for them to get hold of elusive migrants. Additionally, they found it hard to sanction migrants who ignored requests from home (2015: 2028). In this sense, both distance and the migrants' relatively powerful position in the relationship worked in the migrants' favour. They could decide to ignore those requests they considered non-essential. Similarly, the bushfallers in Freiburg were intent on eliminating fraudulent or 'unnecessary' demands from home. Miranda explained that she made promises and sent money only for morally meaningful expenditures: 'It is usually [for] illness, maybe when my mother is sick, and not promises for any rubbish.' Her strong stance against sending remittances for unwanted consumption was against the backdrop of her experience that non-migrants use mobile phones to 'unnecessarily ask money just like that'. She said this with a dismissive hand gesture, indicating the ease with which money is requested.

Migrants' emphasis on what is 'important', 'serious' or 'rubbish' reveals their ability to speak authoritatively to their relatives, and also that they have the final decision on which remittances are essential. Most of them acknowledged that life is hard in Cameroon, and that they could understand why family members were tempted to use the pretext of an emergency to request money. On the other hand, they doubted whether the money demanded was for genuine purposes. In fact, migrants often used the pretext of physical absence from Cameroon to refuse financial support to those who might even be in need. They argued that they could not directly observe non-migrants' lives and lifestyles. This absence of co-locality supported the bushfallers' suspicion that the mobile phone was being used to request money to pay for 'illegitimate' consumption. In part, the suspicion that money is used for 'illegitimate' consumption hinges on personal experiences of dishonesty from home. But the greater part of this suspicion draws on an awareness that the mobile phone is frequently used for deceitful purposes in Cameroonian transnational remittance requests.

The narrative that health is 'something serious' suggests that migrants are keen to exercise responsibility and cultural obligations to support their family members when they are in need. But underlying these feelings of responsibility and obligation were aspects of guilt, the wish to free their consciences, and the wish to maintain social ties in ways that proved they were (still) attached to the family. In other words, some of the bushfallers fulfilled obligations to send remittances for healthcare in part because they were concerned with maintaining their good reputation within the family. For instance, Francis stated that migrants would feel guilty if they did not intervene immediately when a family member required urgent medical attention. He described having a cordial relationship with his cousin, with whom he communicated on a regular basis through phone calls and emails. Francis was aware that his cousin's daughter was ill, but he did not know the gravity of the illness. He related:

All of a sudden, she called later and told me to send her money. She said she was sick with typhoid together with the child. She said they needed to go to the hospital and that the child's situation was being monitored. She expressed sorrow and distress ... You see, they present demanding and desperate situations. What could I have done? I reasoned that if I 
did not send them the money, they could in turn blame me if anything went wrong - she having further complications and blaming me for not helping her.

Francis responded accordingly by sending the exact amount of money requested by his cousin. Migrants who felt obliged to send remittances for healthcare did not want to feel guilty, or be held accountable if someone had further complications or died because they lacked the money to go to hospital for treatment. It is common in Cameroonian transnational family relationships to accuse and blame migrants for neglecting the family who stays at home (Tazanu and Frei 2017; Alpes 2012; Tazanu 2012b; 2015a). Bushfallers are often made to feel guilty if they fail to financially intervene to help those who stay behind. The part played in this scenario by new media, especially the mobile phone, is that it provides an avenue for non-migrants to make claims as well as to incite feelings of guilt in those who are expected to reciprocate. Francis, and other migrants, reported that the mobile phone provided an easy channel for families in Cameroon to instantly shift responsibilities of healthcare to bushfallers. They were either asked to pay the total bill or expected to contribute the greater share of the total. In families with more than one migrant however, it is common to hear of quarrels, miscommunication and misinformation about money destined for healthcare. It is often the case that non-migrants request such money from multiple sources without informing all of the remitters involved (Nyamnjoh 2005). When the migrant family members become aware that money has been requested from several sources to pay for a single health problem, they accuse non-migrants of playing confidence tricks on their kin.

This practice of deceiving relatives through the mobile phone demonstrates how the technology is uncomfortably embedded in Cameroonian transnational relationships. It is precisely because of this unease that migrants expressed a strong willingness to disconnect, or to engage in 'shallow sociality' (Tazanu 2012b: 210). In our recently published article, Bettina Frei and I define shallow sociality as 'a furtive type of mediated interaction in which the actors responsible for nurturing the ties fear asking questions that could generate intimacy or closeness' (Tazanu and Frei 2017: 86-7). Most migrants I interviewed preferred ignorance: they chose not to know if someone was sick in the family. They would opt to remain silent and feign ignorance, and they would not seek further information if they learned about an ill relative or friend not socially close to them. An open acknowledgement of someone's ill health would mean that they could be compelled to remit money to that person. This is because, as I have argued above, a sick person's request for remittances has legitimacy. Ignorance in this context serves the strategic value of shielding and protecting individuals who would otherwise feel responsible.

This preference on the part of the migrants to keep relationships as shallow as possible should not undermine my observation that they also wanted to maintain the high regard of their family as far as the health of their parents or siblings was concerned. The migrants I interviewed were aware of bitterness among family and friends that had resulted from unmet expectations of remittances. Bushfallers also knew that people in Cameroon portrayed them as rich, but irresponsible, people. They were described as greedy children lacking in compassion if they did not send money for their parents' healthcare in Cameroon (see also Abranches 2014). Generally, people in Cameroon lose respect if they fail to take care of their 
ageing parents (see also Drotbohm and Alber 2015: 11; Mazzucato 2008). There are usually retaliatory measures such as gossip and rumour aimed at ridiculing irresponsible children, and this retaliation is exaggerated when the children in question are migrants (Tazanu 2012a). These children are accused of pursuing the personal accumulation of wealth at the expense of their parents' well-being. During my fieldwork in Buea, there were rumours about migrants who had abandoned their sick and ailing parents. Some of the participants contended that these parents should ideally be living with their migrant children, as is the case with most Cameroonian families. The allegedly suffering parents were portrayed as unfortunate victims of their successful but uncaring children.

\section{Conclusion}

In this article, I have highlighted the impact of the mobile phone on expectations of reciprocity in transnational relationships, with a specific focus on the unease that arises from direct requests for remittances. It should be noted that bushfallers do not remit money only for morally meaningful exigencies such as health, education and funerals. There was plenty of evidence that migrants in Freiburg periodically sent small amounts of money to their parents, siblings, relatives and some friends without linking it to any defined item or service. It was left to the discretion of the recipients to spend the money as they wished. Introducing the mobile phone into the scenario, however, changed this situation completely. The fact that the medium provides avenues for non-migrants to instantly articulate financial needs appears to be the most vexing issue in contemporary Cameroonian transnational social ties (see also Tazanu 2015a; Tazanu and Frei 2017: 86-7). This is further exacerbated by the suspicion that non-migrants such as the young people in Buea regard financial support from family members abroad as an entitlement. Many of them consider the remittances as resources they can consume without being accountable to anyone. In Cameroonian parlance, they 'eat' or 'chop' (enjoy frivolously) the money (see also Frei 2012; 2013; Tazanu 2012a; 2015a). But that migrants disapprove of non-migrants' consumption expectations is made evident in what bushfallers prioritize as 'legitimate' consumption, as exemplified by the case of healthcare support.

These findings expand the boundaries of the anthropology of new media as well as the anthropology of exchange. We might be tempted to see ICT as necessarily beneficial to transnational family ties because, prior to the availability of these technologies, most transnational family relationships were strained by distance and slow communication (Mahler 2001: 583-5; Vertovec 2009: 56). I have demonstrated that one of the flip sides of direct communication in transnational relationships is the unmet hope that using a mobile phone will serve to help fulfil expectations of reciprocity. This is evident in the tensions, quarrels and examples of unease that are instantly mediated. Thus, instant communication does not necessary strengthen social ties. Furthermore, the use of the phone to demand reciprocity directly challenges the classic literature on the anthropology of exchange, which tends to suggest that actors who give are patient in anticipating reciprocation of their gifts. Unlike this classic literature, which also says that gifts foster social bonds by binding actors who feel obliged to reciprocate, the case I 
present here reveals that using new media to ask directly for remittances instead contributes to friction in transnational family bonds.

\section{Acknowledgements}

This article draws on my $\mathrm{PhD}$, which was sponsored by the Volkswagen Foundation in Hanover through 'Passages of Culture: Media and Mediations of Culture in African Societies'. I sincerely thank the Foundation for the financial support. Sincere thanks also to the National Research Foundation of South Africa for funding my postdoctoral research at the Wits Centre for Diversity Studies, University of the Witwatersrand. Thanks to the two anonymous reviewers, Judith Schlehe and Scott Burnett for their insightful inputs.

\section{References}

Abranches, M. (2014) 'Remitting wealth, reciprocating health? The "travel" of the land from Guinea-Bissau to Portugal', American Ethnologist 41 (2): 261-75.

Åkesson, L. (2011) 'Remittances and relationships: exchange in Cape Verdean transnational families', Ethnos 76 (3): 326-47.

Alpes, M. (2012) 'Bushfalling at all cost: the economy of migratory knowledge in Anglophone Cameroon', African Diaspora 5 (1): 90-115.

Alpes, M. J. (2017) 'Why aspiring migrants trust migration brokers: the moral economy of departure in Anglophone Cameroon', Africa 87 (2): 304-21.

Andersen, B. (2013) 'Tricks, lies, and mobile phones: "phone friend" stories in Papua New Guinea', Culture, Theory and Critique 54 (3): 318-34.

Ardener, E., S. Ardener and W. Warmington (1960) Plantation and Village in the Cameroons: some economic and social studies. Oxford: Oxford University Press.

Argenti, N. (2007) The Intestines of the State: youth, violence, and belated histories in the Cameroon Grassfields. Chicago IL: University of Chicago Press.

Brain, R. (1972) Bangwa Kinship and Marriage. London: Cambridge University Press.

Carling, J. (2014) 'Scripting remittances: making sense of money transfers in transnational relationships', International Migration Review 48 (S1): 218-62.

Carrier, J. (1991) 'Gifts, commodities, and social relations: a Maussian view of exchange', Sociological Forum 6 (1): 119-36.

Cole, J. (2014) 'The télèphone malgache: transnational gossip and social transformation among Malagasy marriage migrants in France', American Ethnologist 41 (2): 276-89.

Couldry, N. (2004) 'Liveness, reality and the mediated habitus from television to the mobile phone', Communication Review 7: 353-61.

Drotbohm, H. (2010) 'Gossip and social control across the seas: targeting gender, resource inequalities and support in Cape Verdean transnational families', Africa and Black Diaspora 3 (1): 51-68.

Drotbohm, H. and E. Alber (2015) 'Introduction' in H. Drotbohm and E. Alber (eds), Anthropological Perspectives on Care: work, kinship, and the life-course. New York NY: Palgrave Macmillan.

Fleischer, A. (2007) 'Family, obligations, and migration: the role of kinship in Cameroon', Demographic Research 16 (13): 413-40. 
Frei, B. (2012) 'I go chop your dollar: scamming practices and notions of moralities among youth in Bamenda, Cameroon' in H. P. Hahn and K. Kastner (eds), Urban Life-worlds in Motion: African perspectives. Bielefeld: Transcript.

Frei, B. (2013) Sociality Revisited?: the use of the internet and mobile phones in urban Cameroon. Bamenda: Langaa Research and Publishing CIG.

Geschiere, P. and J. Gugler (1998) 'Introduction: the urban-rural connection: changing issues of belonging and identification', Africa 68 (3): 309-19.

Hernández-Carretero, M. (2015) 'Renegotiating obligations through migration: Senegalese transnationalism and the quest for the right distance', Journal of Ethnic and Migration Studies 41 (12): 2021-40.

Horst, H. (2006) 'The blessings and burdens of communication: cell phones in Jamaican transnational social fields', Global Networks 6 (2): 143-59.

Horst, H. and D. Miller (2006) The Cell Phone: an anthropology of communication. Oxford: Berg.

Hunter, A. (2015) 'Empowering or impeding return migration? ICT, mobile phones, and older migrants' communications with home', Global Networks 15 (4): 485-502.

Jackson, K. (2014) 'Intimacies and distances: mobility, belonging and the use of information and communication technologies by young Cameroonians in Cape Town'. PhD thesis, University of Cape Town.

Jua, B. (2003) 'Differential responses to disappearing transitional pathways: redefining possibility among Cameroonian youths', African Studies Review 46 (2): $13-36$.

Jua, N. (2005) 'The mortuary sphere, privilege and the politics of belonging in contemporary Cameroon', Africa 75 (3): 325-55.

Lindley, A. (2009) 'The early-morning phonecall: remittances from a refugee diaspora perspective', Journal of Ethnic and Migration Studies 35 (8): 1315-34.

Madianou, M. and D. Miller (2011) 'Mobile phone parenting: reconfiguring relationships between Filipina migrant mothers and their left-behind children', New Media Society 13 (3): 457-70.

Mahler, S. (2001) 'Transnational relationships: the struggle to communicate across borders', Identities 7 (4): 583-619.

Mata-Codesal, D. (2015) 'Ways of staying put in Ecuador: social and embodied experiences of mobility-immobility interactions', Journal of Ethnic and Migration Studies 41 (14): 2274-90.

Mauss, M. (1954) The Gift: forms and functions of exchange in archaic societies. London: Routledge.

Mazzucato, V. (2008) 'Transnational reciprocity: Ghanaian migrants and the care of their parents back at home' in E. Alber, S. van der Geest and S. Whyte (eds), Generations in Africa: connections and conflicts. Bayreuth: Institut fur AfrikaStudies.

McKay, D. (2007) “"Sending dollars shows feeling”: emotions and economies in Filipino migration', Mobilities 2 (2): 175-94.

Miller, D. and D. Slater (2000) The Internet: an ethnographic approach. Oxford: Berg.

Mullings, B. (1999) 'Insider or outsider, both or neither: some dilemmas of interviewing in a cross-cultural setting', Geoforum 30 (4): 337-50.

Nkwi, W. (2009) 'From the elitist to the commonality of voice communication: the history of the telephone in Buea, Cameroon' in M. De Bruijn, F. Nyamnjoh and 
I. Brinkman (eds), Mobile Phones: the talking drums of everyday Africa. Bamenda: Langaa Research and Publishing CIG.

Nyamnjoh, F. (2002) 'A child is one person's only in the womb: domestication, agency and subjectivity in the Cameroonian Grassfields' in R. Werbner (ed.), Postcolonial Subjectivities in Africa. London: Zed Books.

Nyamnjoh, F. (2004) 'Global and local trends in media ownership and control: implications for cultural creativity in Africa' in W. van Binsbergen and R. van Dijk (eds), Situating Globality: an African agency in the appropriation of global culture. Leiden: Brill.

Nyamnjoh, F. (2005) 'Images of Nyongo amongst Bamenda Grassfielders in Whiteman Kontri', Citizenship Studies 9 (3): 241-69.

Nyamnjoh, F. (2011) 'Cameroonian bushfalling: negotiation of identity and belonging in fiction and ethnography', American Ethnologist 38 (4): 701-13.

Ouden, J. (1987) 'In search of personal mobility: changing interpersonal relations in two Bamileke chiefdoms, Cameroon', Africa 57 (1): 3-27.

Rowlands, M. (1996) 'The consumption of an African modernity' in M. Arnoldi, C. Geary and K. Hardin (eds), African Material Culture. Indianapolis IN: Indiana University Press.

Salzman, P. (2002) 'On reflexivity', American Anthropologist 104 (3): 805-13.

Sherry, J. (1983) 'Gift giving in anthropological perspective', Journal of Consumer Research 10 (2): 157-68.

Simoni, V. (2015) 'Intimacy and belonging in Cuban tourism and migration', Cambridge Journal of Anthropology 33 (2): 26-41.

Sultana, F. (2007) 'Reflexivity, positionality and participatory ethics: negotiating fieldwork dilemmas in international research', ACME: An International Journal for Critical Geographies 6 (3): 374-85.

Tazanu, P. (2010) 'Border transgression and the reordering of social relations: the case of Cameroonian migrants in Germany', Freiburgeruniversitätsblätter Heft 188: 81-92.

Tazanu, P. (2012a) 'They behave as though they want to bring heaven down: some narratives on the visibility of Cameroonian migrant youths in Cameroon urban space' in H. P. Hahn and K. Kastner (eds), Urban Life-worlds in Motion: African perspectives. Bielefeld: Transcript.

Tazanu, P. (2012b) Being Available and Reachable: new media and Cameroonian transnational sociality. Bamenda: Langaa Research and Publishing CIG.

Tazanu, P. (2015a) 'On the liveness of mobile phone mediation: youth expectations of remittances and narratives of discontent in the Cameroonian transnational family', Mobile Media and Communication 3 (1): 20-35.

Tazanu, P (2015b) 'New media and expectations of social closeness: the mobile phone and narratives of "throwing people away" in Cameroonian transnational social relationships', Modern Africa: Politics, History, and Society 3 (2): 101-26.

Tazanu, P. and B. Frei (2017) 'Closeness, distance and disappearances in Cameroonian mediated transnational social ties: uses of mobile phones and narratives of transformed identities', Journal of African Media Studies 9 (1): 77-90.

Tsuda, T. (1998) 'Ethnicity and the anthropologist: negotiating identities in the field', Anthropological Quarterly 71 (3): 107-24.

Vertovec, S. (2009) Transnationalism. New York NY: Routledge.

Weiner, A. (1980) 'Reproduction: a replacement for reciprocity', American Ethnologist 7 (1): 71-85. 
Wiles, J. (2008) 'Sense of home in a transnational social space: New Zealanders in London', Global Networks 8 (1): 116-37.

\begin{abstract}
Research on the significance of the mobile phone and internet in transnational family relationships shows that these media provide direct platforms for negotiating remittances. My interest in this article is not so much in how they are used to coordinate and channel money home as in their appropriation to meet expectations of reciprocity. The article draws from field narratives collected among Cameroonians in Germany and in Cameroon to reveal contestations over what can be described as legitimate consumption within the Cameroonian transnational social sphere. Underlying the arguments in this article is my observation that direct communication within the Cameroonian transnational sphere is beset by so much mistrust, discontent and uncertainty that remitters must specify what they are remitting money for. Healthcare in Cameroon is considered an expenditure that is worthy of migrants' financial support.
\end{abstract}

\title{
Résumé
}

La recherche sur l'importance du téléphone mobile et de l'Internet dans les relations familiales transnationales montre que ces supports servent de plateformes directes de négociation de transferts de fonds. Dans cet article, l'auteur ne s'intéresse pas tant à leur mode d'utilisation pour coordonner et acheminer les fonds vers le pays d'origine que leur appropriation pour satisfaire les attentes de réciprocité. L'article s'appuie sur des récits de terrain recueillis auprès de Camerounais en Allemagne et au Cameroun pour révéler des contestations sur ce que l'on peut décrire comme une consommation légitime dans la sphère sociale transnationale camerounaise. À la base des arguments présentés dans cet article, l'auteur observe que la communication directe dans la sphère transnationale camerounaise est en proie à tant de méfiance, de mécontentement et d'incertitude que les remettants doivent préciser le motif des transferts de fonds. Au Cameroun, la santé est considérée comme une dépense qui mérite le soutien financier des migrants. 